\section{Early diagnosis of leptospirosis}

\author{
Andrea Babic-Erceg,' \\ Diana Karlovic-Martinkovic, ${ }^{1}$ \\ Marija Santini, ${ }^{2}$ Zdenka Persic, ${ }^{1}$ \\ Tatjana Vilibic-Cavlek ${ }^{1}$
}

${ }^{1}$ Croatian National Institute of Public Health, Zagreb; ${ }^{2}$ University Hospital for Infectious Diseases Dr. Fran Mihaljevic, Zagreb, Croatia

\section{Abstract}

A 25-years old man from Zagreb, Croatia, was admitted to the University Hospital for Infectious Diseases four days after the onset of symptoms such as fever, intense pain in the calves and anuria. The patient owned a rabbit and, before the onset of the disease, repaired some rubber pipes damaged by rodents. At admission, he had a severe clinical picture with fever, hypotension, jaundice, immobility, and pain in leg muscles. Treatment with ceftriaxone was initiated in combination with volume restitution. Renal failure soon ensued. Consequently continuous venovenous hemodiaphiltration therapy was performed. Due to acute respiratory distress syndrome, the patient was mechanically ventilated. The patient's condition gradually improved and he recovered fully from multi-organ failure. Diagnosis was confirmed by a microscopic agglutination test (MAT) covering 15 leptospira serovars and real-time polymerase-chain reaction (PCR). The first serum sample taken on day 6 tested negative for leptospira, while PCR showed positive results for leptospiral DNA. The second serum sample taken on day 13 tested positive for serovar Canicola serogroup Canicola, serovar Patoc, serovar Grippotyphosa serogroup Grippotyphosa and serovar Tarassovi serogroup Tarassovi (titre 4000, 4000, 1000 and 2000, respectively), while PCR was negative. This report highlights the benefits of combining MAT and PCR methods in early diagnosis of leptospirosis.

\section{Introduction}

Leptospirosis represents an emerging public health problem worldwide. It is a zoonosis caused by bacteria that belongs to the Leptospira genus, Leptospiraceae family, Spirochetales order. The Leptospira genus consists of the pathogenic - Leptospira interrogans sensu lato and non-pathogenic - Leptospira biflexa sensu lato group. ${ }^{1}$ There are more than 200 pathogenic serovars. Classification into species, serogroups, serovars and strains is complicated and genotypic classification differs from serological classification. ${ }^{2-5}$ Bacteria live in renal tubules of carrier animals and are excreted by the urine. Leptospira are present in the blood and cerebrospinal fluid (CSF) in the first seven to ten days from disease onset, when direct diagnosis is possible. They appear in the urine at the beginning of the second week and are excreted for up to 30 days. $^{6}$ Polymerase-chain reaction (PCR) testing on blood, serum, urine, CSF and tissue samples can be performed in these cases. Antibodies appear five to ten days from the onset of disease or later, when their presence can be proven by microscopic agglutination (MAT). ${ }^{7}$ The span of tested serovars depends on strains circulating in a particular area. ${ }^{8,9}$ Over the last decade, between 22 and 137 cases of human leptospirosis were reported annually in Croatia. ${ }^{10}$ We report a case of leptospirosis occurred in Croatia in order to demonstrate the need for combined MAT and PCR for an early diagnosis of this disease.

\section{Case Report}

A twenty-five years old patient from Zagreb, Croatia, was admitted to the University Hospital for Infectious Diseases Dr Fran Mihaljevic, four days after the onset of symptoms such as fever, intense pain in the calves and anuria.

Epidemiological history revealed that the patient recently visited a village near Zagreb, where he repaired rubber pipes damaged by rodents around a house and cleaned the porch. The patient reported the presence of skin abrasions on his hands. It is to be noted that the patient also owned a rabbit.

At admission, he had a severe clinical picture with fever, hypotension, tachycardia, jaundice, immobility, moderate conjunctival injection and pain in his leg muscles. Laboratory tests showed leukocytosis, elevated C-reactive protein, liver enzymes, urea and creatinine (Table 1). The electrocardiogram detected sinus tachycardia and incomplete right bundle branch block. Chest radiograph performed on day 2 revealed an extensive infiltrate in the left lung and non-cardiac pulmonary edema. Ultrasound of the abdomen showed moderate hepatomegaly with a diffuse lesion, a layer of free liquid surrounding the gall-bladder and enlarged kidneys. The patient was admitted to the intensive care unit (ICU) due to worsening his health conditions and circulatory collapse.

Treatment with ceftriaxone was initiated due to the suspicion of leptospirosis, with volume restitution and vasopressor therapy. The disease rapidly progressed and renal failure ensued.
Correspondence: Andrea Babic-Erceg, Croatian National Institute of Public Health, Rockefellerova 7, 10000 Zagreb, Croatia.

Tel.: +385.1486 .3260$

E-mail: andrea.babic.erceg@hzjz.hr

Key words: leptospirosis, microscopic agglutination test, polymerase chain reaction.

Contributions: the authors contributed equally.

Conflict of interests: the authors declare no potential conflict of interests.

Received for publication: 4 November 2013 Revision received: 19 December 2013. Accepted for publication: 2 January 2014.

This work is licensed under a Creative Commons Attribution NonCommercial 3.0 License (CC BYNC 3.0).

(C) Copyright A. Babic-Erceg et al., 2014 Licensee PAGEPress, Italy

Infectious Disease Reports 2014; 6:5156 doi:10.4081/idr.2014.5156

Short-term continuous venovenous hemodiaphiltration therapy was performed. Due to a severe pneumonitis and acute respiratory distress syndrome (diagnosed by chest $\mathrm{X}$-ray), the patient was mechanically ventilated and intubated over five days. The patient received 14 days of antimicrobial therapy. His condition gradually improved and full recovery from multiorgan failure has been achieved. The patient was discharged home after 21 days of hospital treatment.

\section{Methods}

Paired serum samples (on day 6 and 13) were tested for leptospira antibodies. MAT was used to test antibodies for 15 locally-occurring serovars of live strains: Grippotyphosa, Sejrö, Australis, Pomona, Canicola, Icterohaemorrhagiae, Tarassovi, Saxköbing, Ballum, Bataviae, Poi, Hardjo, Autumnalis, Mitis and Patoc. The endpoint was the highest dilution of serum in which $50 \%$ agglutination occured. ${ }^{7,9}$ Although in areas where leptospirosis is endemic, a single titer of $>800$ in symptomatic patients is generally indicative of leptospirosis, titers as high as $>1600$ have been recommended. ${ }^{11}$ The serum was analyzed with real-time PCR (TaqMan kit). The first step was DNA extraction from the patient serum using commercial QIAamp DNA Mini kit (QIAGEN, Venio, the Netherlands), according to manufacturer's instructions. The primers and the probe for the detection of the rrs (16S) gene were taken from the GenBank nucleotide sequence database [ Lep toF ( ${ }^{\prime}{ }^{171}$ CCCGCGTCCGATTAG 3 '), LeptoR(5 ${ }^{\text {} 558}{ }^{2}$ TCCATTGTGGCCGR ${ }^{\mathrm{AG} A C A C} 3$ '), pro be $\left[5^{\prime 205}(\mathrm{FAM})\right.$ CTCACCAAGGCGACGATCG- 
Table 1. Laboratory results demonstrating disease progression and regression.

\begin{tabular}{lcccccc}
\hline Test & Day 5 & Day 6 & Day 8 & Day 12 & Day 20 & Range \\
CRP $(\mathrm{mg} / \mathrm{L})$ & 206.7 & NT & 68.3 & 36.8 & 4.8 & $<5.0$ \\
WBC $\left(\times 10^{9} / \mathrm{L}\right)$ & 13.8 & 20.8 & 12.9 & 20.8 & 9.8 & $4.0-10.0$ \\
\hline Platelets $\left(\times 10^{9} \mathrm{~L}\right)$ & 42 & 34 & 81 & 220 & 328 & $100-400$ \\
RBC $\left(\times 10^{12} / \mathrm{L}\right)$ & 3.83 & 2.86 & 2.44 & 2.53 & 3.70 & $4.4-5.8$ \\
\hline Hemoglobin $(\mathrm{g} / \mathrm{L})$ & 118 & 88 & 76 & 78 & 91 & $140-180$ \\
Bilirubin $(\mu \mathrm{mol} / \mathrm{L})$ & 96.8 & 194.6 & 241.6 & 145.9 & 91.0 & $3.0-20.0$ \\
\hline Urea $(\mathrm{mmol} / \mathrm{L})$ & 7.4 & 12.1 & $11.9^{*}$ & 18.9 & 7.4 & $2.8-8.3$ \\
Creatinine $(\mu \mathrm{mol} / \mathrm{L})$ & 129 & 288 & $195^{*}$ & 177 & 138 & $79-125$ \\
\hline AST $(\mathrm{U} / \mathrm{L})$ & 136 & 170 & 128 & 71 & 96 & $11-38$ \\
ALT $(\mathrm{U} / \mathrm{L})$ & 73 & 64 & 70 & 105 & 279 & $12-48$ \\
\hline GGT $(\mathrm{U} / \mathrm{L})$ & 145 & 100 & 68 & 75 & 87 & $11-55$ \\
LDH $(\mathrm{U} / \mathrm{L})$ & 243 & 215 & 250 & 679 & 452 & $<241$ \\
\hline CK $(\mathrm{U} / \mathrm{L})$ & $\mathrm{NT}$ & 3911 & 654 & 237 & 44 & $<177$ \\
\hline
\end{tabular}

NT, not tested; CRP, C-reactive protein; WBC, white blood cells; RBC, red blood cells; AST, aspartate-aminotransferase; ALT, alanine-aminotransferase; GGT, gamma-glutamyltransferase; LDH, lactate dehydrogenase; CK, creatinine kinase. *Value on continuous veno-venous hemodiafiltration.

Table 2. Results of the microscopic agglutination test for leptospira.

\begin{tabular}{lc} 
Serovar & Antibody titre* \\
Grippotyphosa & 1000 \\
Sejrö & Negative \\
\hline Australis & Negative \\
Pomona & Negative \\
\hline Canicola & 4000 \\
Icterohaemorrhagiae & Negative \\
\hline Tarassovi & 2000 \\
Saxköbing & Negative \\
Ballum & Negative \\
\hline Bataviae & Negative \\
Poi & Negative \\
\hline Hardjo & Negative \\
Autumnalis & Negative \\
\hline Mitis & Negative \\
Patoc & 4000 \\
\hline *Reciprocal value of the highest serum dilution which shows posi- \\
tive result.
\end{tabular}

GTAGC $^{228}$ 3' (TAMRA)]. Amplification and detection were carried out on the ABI Prism 7500 detector (Applied Biosystems, Carlsbad, USA), on a 40 cycle program (each cycle at $95^{\circ} \mathrm{C} / 15^{\prime \prime}$ and $60^{\circ} \mathrm{C} / 1$ '). ${ }^{12} \mathrm{~A}$ negative result was assigned where no amplification occurred, i.e. when the threshold cycle $(\mathrm{Ct})$ value was greater than 40 cycles.

\section{Results}

The first serum sample collected on day 6 tested negative for leptospira in MAT, while PCR showed a positive result for leptospiral DNA. The second serum sample taken on day 13 was positive in MAT for serovar Canicola serogroup Canicola, serovar Patoc, serovar Grippotyphosa serogroup Grippotyphosa and serovar Tarassovi serogroup Tarassovi (titre 4000, 4000, 1000 and 2000, respectively) (Table 2), whereas it tested PCR negative. The CT (crossing threshold) value of the initial serum was 38 , the second was $>40$ and was considered negative. There was no inhibition.

\section{Discussion and Conclusions}

Rapid and early diagnosis of leptospirosis patients, since the antibiotic therapy is more effective, when initiated early in the course of the disease. ${ }^{13}$ Most cases of leptospirosis are diagnosed through serology with MAT as the reference serological method. Seroconversion may occur as early as 5 to 7 days after the onset of the disease, but sometimes it takes 10 days or longer. In addition, patients with fulminant leptospirosis may die before seroconversion occurs. Cross-reaction with several serovars is often observed in the initial phase of infection. ${ }^{14}$ The diagnostic advantage of PCR over serology is particularly relevant during the very early stages of the infection. ${ }^{15}$ However, the limitation of this method is its inability to identify the serovar. ${ }^{16}$ Furthermore the sensitivity of PCR in the early acute phase ranges from $60-100 \% .{ }^{17}$ In this patient the first serology was negative for leptospira, while PCR was positive, whereas the second serology showed positive leptospira antibodies.

This case highlights the importance of combining serology (confirmed acute infection by seroconversion in paired serum samples) and molecular techniques in the early diagnosis of leptospirosis. plays a significant role in the treatment of

\section{References}

1. Faine S, Adler B, Bolin C, Perolat P. Leptospira and leptospirosis, 2nd ed. Melbourne: MediSci; 1999.

2. Brenner DJ, Kaufmann AF, Sulzer KR, et al. Further determination of DNA relatedness between serogroups and serovars in the family Leptospiraceae with proposal for Leptospira alexanderi sp. nov. and four new Leptospira genomospecies. Int J Syst Bacteriol 1999;49:839-58.

3. Adler B, Lo M, Seemann T, Murray GL. Pathogenesis of leptospirosis: the influence of genomics. Vet Microbiol 2011;153:73-81.

4. Adler B, de la Peña Moctezuma A. Leptospira and leptospirosis. Vet Microbiol 2010;140:287-96.

5. Bharti AR, Nally JE, Ricaldi JN, et al. Leptospirosis: a zoonotic disease of global importance. Lancet Infect Dis 2003;3:757-71.

6. Nevjesti A, Andrijani M. Leptospiroze (Leptospiroses). Degree Diss., Faculty of Veterinary Medicine, University of Sarajevo, Bosnia and Herzegovina; 2009.

7. WHO. Human leptospirosis guidance for diagnosis, surveillance and control. Geneva: WHO; 2003.

8. Wasi ski B. [Leptospirosis-current problems]. Przegl Epidemiol 2011;65:471-6. [Article in Polish].

9. Prostic D, Merien F, Perolat P, Baranton G. Diagnostic biologique leptospirose - boreliose de Lyme (Biological diagnosis leptospirosis- Lyme boreliosis). 2nd ed. Paris: Collection des Laboratoires de Reference et d'Expertise: Institut Pasteur a Paris; 2000. pp 177-186.

10. Croatian National Institute of Public Health (CNIPH). Croatian health service yearbook. Zagreb: CNIPH; 2001-2011.

11. Levett PN. Leptospirosis. Clin Microbiol Rev 2001;14:296-326.

12. Smythe LD, Smith IL, Smith GA, et al. A quantitative PCR (TaqMan) assay for pathogenic Leptospira spp. BMC Infect Dis 2002;2:13.

13. Toyokawa T, Ohnishi M, Koizumi N. Diagnosis of acute leptospirosis. Expert Rev Anti Infect Ther 2011;9:111-21.

14. Levett PN. Leptospira. In: Versalovic J, Carroll KC, Funke G, et al, eds. Manual of clinical microbiology. 10th ed. Washington: ASM Press; 2011. pp 916-23.

15. Katz AR. Quantitative polymerase chain reaction: filling the gap for early leptospirosis diagnosis. Clin Infect Dis 2012;54:1256-8.

16. Musso D, La Scola B. Laboratory diagnosis of leptospirosis: a challenge. J Microbiol Immunol Infect 2013;46:245-52.

17. Picardeau M. Diagnosis and epidemiology of leptospirosis. Med Mal Infect 2013;43:1-9. 